\title{
IAMJ
}

INTERNATIONAL

AYURVEDIC

MEDICAL JOURNAL

\section{A COMPARATIVE STUDY OF GUDUCHYADI YOGA AND MEDOHAR GUGGULU IN THE MANAGEMENT OF MEDOROGA}

\section{Anita Renni}

MD, Ph.D (Kayachikitsa), Professor \& HOD, Department of Kayachikitsa, Mannam Ayurveda Co-operative Medical College, Pandalam, Kerala, India

Corresponding Author: dranitarenni@gmail.com

\section{https://doi.org/10.46607/iamj06p5012020}

(Published online: November 2020)

Open Access

(C) International Ayurvedic Medical Journal, India 2020

Article Received: 15/11/2020 - Peer Reviewed: 26/11/2020 - Accepted for Publication: 27/11/2020

Check for updates

\begin{abstract}
W.H.O. has evolved a social target of "Health for all" by the year 2000. To achieve this Indian Govt. has a evolved number of health and social policies. In these "Prevention" plays an important role. To reach this goal, promotion of health, raising the standards of community health and prevention of the disease is important.

People know what to eat but they don't know how to eat. Acharya Charaka has mentioned Aharavidhividhana (dietary guidelines), the dietic rules and codes of conduct for every season. Now-a-days people do not follow the rules of diet intake and regimen mentioned in Ritucharya (seasonal regimen). This has invited increased incidence of diseases like Amlapitta (hyperacidity), Prameha (Diabetes mellitus), Hridroga (Heart disease), Medoroga (Obesity) etc. In the context of Medoroga, Madhukosha mentions Sneha (oil or fat) as the factor from which Meda (fat) is formed. All the Dhatu nourishes mainly by Sneha. So excess intake of fat leads to excess deposition of lipid in the body. Two groups were registered to compare the effectiveness of Guduchyadi Yoga and Medohar Guggulu in the above disease. In group A, out of 25 patients, 14 patients (56\%) were treated effectively, 04 patients (16\%) had moderate improvement, 02 (08\%) had mild improvement, while $05(20 \%)$ showed insignificant result. In group B, out of 25 patients 09 patients $(36 \%)$ were treated effectively, $02(08 \%)$ patients had moderate improvement, $01(04 \%)$ patient had mild relief while 13 patients $(52 \%)$ showed insignificant result.
\end{abstract}


Although satisfactory result obtained on various parameters with Medohar Guggulu but Guduchyadi Yoga is highly effective remedy for Medoroga as compared to Medohar Guggulu.

Keywords: Obesity, Medoroga, Sneha, Ritucharya, Athishoulya (Overweight).

\section{INTRODUCTION}

Obesity is a medical condition in which excess body fat has accumulated to the extent that it may have a negative effect on health. Obesity is a life-threatening disease. Obese people are more likely than others to develop major illnesses such as cardiovascular diseases, gall bladder diseases, DM and certain cancer. People are considered obese when their BMI exceeds $30 \mathrm{~kg} / \mathrm{m}^{2}$.

In Ayurveda, text Acharya Charaka has described eight Ninditiyapurushas ${ }^{[1]} \quad$ (undesirable persons/ conditions) according to body constitution \& obesity is one of them. In Ayurveda Obesity (Atisthoulya) is described as "Medoroga". Atishoulya (overweight) is considered as one of the eight despicable condition as described in Charak Samhita. A person in whom there is excessive accumulation of Meda (adipose tissue) and Mamsa (flesh) leading to flabbiness of hips, abdomen and breast has been categorised as Atisthoulya. Increase Meda is accountable for several serious consequences called Ashtadoshas ${ }^{[2]}$ (eight defects/flaw) like Ayuhrasa (decrease of life span), Javoparodha (decrease in enthusiasm and activity), Krichavyavayata (decrease in sexual act), Daurbalya (decrease of strength), Daurgandhya (bad odour), Swedabadh (excess perspiration) and Kshutpipasadhikya (excessive hunger and thirst), Mandotsaham (less activity) referring to sedentary life style. Atisnigdha (excessive intake of fatty substances) and Kshudhavriddhi (excessive eating) constitute for causation of Prameha and these etiological factors may initiate Dislipidemia.

Being an alarming problem, obesity needs effective and safe treatment. In the management of obesity Bhutagni [fire of five basic elements i.e. Parthiva (earth), Apya (water), Tejas (fire), Vayavya (air) and Akash (Sky-vacuum)] \& Dhatwagni (Seven fire present one in each of the seven tissues) plays an important role ${ }^{[3]}$ so in Ayurveda there is wide scope of research to find out safest remedy for the management of obesity. Ayurvedic medicines by the means of its Doshashaman [Pacification/suppression of Doshas (three humours Vata, Pitta \& Kapha)] and Shodhan property (elimination) may prove to be better option in present situation. An effective management can be done other than only diet control. In present work a comparative study has been made to see the effect of Guduchyadi Yoga \& Medohar Guggulu in the management of obesity.

\section{Literature Survey:}

In Charak Samhita, 'Charakacharya' has described eight 'Nindatiyaprakruties'(undesirable constitution) according to the body constitution. Among them, he has also mentioned Atishoulya. Acharya Susruta has described the aetiology, signs, symptoms and management of Sthoulya (obesity) in detail ${ }^{[4]}$. In the 'Doshadividhivijnana' Adhyaya (chapter) of Sutrasthana, Vagbhata has described the symptoms of Medovriddhi (excess fat) which are similar to Atisthoola of Charaka ${ }^{[5]}$. In Madhavnidan,

Madhavacharya has made separate chapters for some diseases which are not separately mentioned in ancient texts e.g. Amavata (Rheumatoid arthritis) Medoroga, Amlapitta. He was the first who named 'Sthoulya' as medoroga ${ }^{[6]}$.

In Sharangadhara Samhita, only name of the disease Medoroga with some decoctions for the treatment are advised $^{[7]}$. Bhavmishra has described the Medoroga in all aspects in Uttarakhand (end part of book) in the chapter "Sthoulyadhikar"[8], aetiopathogenesis view is same as Charak and Susruta but slight variations are noticed in the treatments. Yoga Ratnakar has described the Medoroga causes, its aetiopathogenesis, symptoms in Medoroganidana (aetiology of obesity) chapter ${ }^{[9]}$, treatment in Medorogachikitsa (treatment of obesity) chapter ${ }^{[10]}$ 


\section{Methodology:}

\section{Aim and Objectives:}

1. To study the aetiopathogenesis of Medoroga (Obesity) according to both Ayurveda and modern science.

2. To assess the comparative effect of Guduchyadi Yoga \& Medohar Guggulu in the management of Medoroga.

\section{Materials and Methods-}

1. Guduchyadi Yoga

2. Medohar Guggulu

Study Design-A minimum of 25 subjects in each group diagnosed as Medoroga were selected after fulfilment of inclusion criteria.

\section{Inclusion Criteria:}

1. Patients age between 16-70 years.

2. Patients willing for the trial $\&$ able to participate for 90 days after consent.

3. Patients suffering from Medaswita (Increase body weight), Nirutsaha (loss of alertness), Daurbalya (weakness), Daurgandhya (Foul smell of body) Kshudhadhikya (Increase appetite), Trishnadhikya (Increase thirst) Kshudraswasa (Dyspnoea on exertion), Sarvangajadhya (Heaviness of body), Atinidra (Sleepiness), Sandhivedana (Knee Joint Pain) were selected irrespective of sex, religion, education, socioeconomic status \& marital status.

4. BMI $>24$

\section{Exclusion Criteria:}

1. Medoroga due to endocrinal disorders like Hypothyroidism, Cushing Syndrome etc.

2. Drug induced obesity and Hyper-lipidemia such as long- term use of OCP, Beta Blockers and corticosteroids.

3. Patients with evidence of Malignancy, Renal failure, Diabetes mellitus, Heart diseases.

\section{Drug Review}

I. Guduchyadi Yoga (Yoga Ratnakar, Medoroga Chikitsa 10/17) ${ }^{10}$

II. Medohar Guggulu: (Bhaishajya Ratnavali Medoroga Chikitsa 39/43) $)^{[11]}$

I. Guduchyadi Yoga: It contains-Guduchi (Tinospora Cordiofolia. Wall. Ex Seringe) Nagarmotha, Triphala choornam [combination of three ingredients i.e. Amalki (Emblica officinalis), Bibhitaki (Terminalia beleric) \& Hareetaki (Terminalia Chebula)] as main ingredients and Takrarishtam \& Madhu as Anupan.

i) Guduchi- It is highly rich in antioxidants. Alkaloids: Berberin, Choline, Tembetarine, Magnoflorine, Tinosporin, Plmetine, Aporphin, Glycosides Tinocordiside, cordioside are present. It is best to cause astringent effect, promoting digestion, alleviating Vata, Kapha. It pacifies all three doshas ${ }^{12}$.

ii) Nagarmotha- Cyperus rotundus ${ }^{12}$.

iii)Hareetaki- Terminaliya Chebula a Tannin, terchebin is isolated from fruits (Ann, Chem. 1967 706,169), Kernels palmitic, stearic, oleic, linoleic, arachidic and behenic acids are isolated. The fruits contain about $30 \%$ astringent substances chebulinic and tannic acid, gallic acid and chebulagic acid etc. By the combination of sweet and sour tastes it alleviates Vata- Dosa, pungent and bitter taste alleviates Kapha Dosa and astringent and sweet alleviates the Pitta Dosa. It has special potency ( Prabhav) to alleviate all the three Dosas. ${ }^{13}$ In obesity, its use with honey reduces the excessive Medas.

iv) Amalki- The botanical name is phyllanthus emblica. Amalki is called Dhatri or nurse as it resembles a nurse or mother in its healing \& soothing properties. Amalki is an all-round tonic \& rejuvenator. The fruit is a rich source of vitamin $\mathrm{C}$, triagalloyglucose, terchebin, corilangin, ellagic acid from fruit. It alleviates all Tridosas ${ }^{14}$.

v) Bibhitaki- In Sanskrit, "Bibhitak literally means the one that keeps you away from the diseases". The botanical term is Terminalia belerica. The fruit pulp contains a non- nitrogenous crystalline substance. A new cardiac glycoside bellericannin- isolated which yield glucose and galactose, B- sitosterol, gallic acid, ellagic acid, ethyl gallate, galloyl glucose and chebulagic acid isolated from fruits. It possesses a special potency (Prabhav) as laxative, it alleviates all the three Dosas specially Kapha and Pitta ${ }^{15}$.

vi) Takrarishtam-It is the poly-herbal acidic fermented preparation from cow milk. It helps to strengthen digestion i.e. Agnideepana. It does not vitiate pitta, is wholesome in Kapha due to astringent, 
hot, Vikasi and rough properties and in Vata due to sweet, sour and viscous nature, thus it pacifies Tridoshas. It has the antimicrobial, Grahi (absorbing), digestive \& carminative properties. It is beneficial in Diabetes, Ascitis, obesity, UTI, Chronic diarrhoea, Prameha, Gulma (abdominal flatulence), Piles, worms etc

v) Madhu -contains high level of monosaccharides, fructose and glucose, organic acids, minerals, trace elements, numerous vitamins, enzymes and proteins. The antioxidant capability of honey is linked to its polyphenol compounds. It has Hypoglycemic, Medohar (Antiobesity) Antiseptic \& antibacterial properties. It alleviates the disorders of Rakta, Pitta and Kapha ${ }^{17}$.

II) Medohar Guggulu- It contains five ingredients i.e. Shunthi, Chitrak, Marich, Pippali, Nagarmotha and Guggulu.

i) Shunthi-The botanical name of Sunthi is Zingiber officinale. Sunthi is one of the ingredients of oftenly used preparation called Trikatu- meaning three pungents viz. Sunthi, Maricha (Piper nigrum) and Pippali (Piper longum). Ginger contains $1-2 \%$ of volatile oil and 5-8\% resinous matter. Starch and mucilage Sunthi alleviate Vata and Kapha Dosas and controls the vitiation of Pitta Dosa ${ }^{18}$.

ii) Chitrak- The botanical name of Chitrak is Plumbago zeylanica. Binaphthaquin one ethitranone together with zeylinone isozeylinone, elliptinone and droserone isolated from roots, Chitrak is pungent and bitter in taste. It alleviates Kapha and Vata dosas. Chitrak digests the Ama, reduces the sotha.(swelling) $)^{19}$

iii) Marich- The fruit contains Volatile oil and the crystalline alkaloids piperine, piperidine and piperettine along with resin. It augments the appetite chiefly Kapha disease, obesity, colds, rheumatic diseases and Tumors ${ }^{20}$.

iv) Pippali- Piper longum. The fruit contain $1 \%$ volatile oil, resin, a waxy alkaloid, a terpenoid substance and alkaloids piperine and piper longumine. It is an appetizer, digestant, rejuvenative, febari funge and a brain tonic (Medhya) and alleviates all the three Dosas. It is a powerful stimulant for the digestive and respiratory system. Trikatu is the most popular formulation used to mitigate the diseases due to Kapha Dosha ${ }^{21}$.

iv) Nagarmotha- The botanical name: Cyperus rotundaus. The plant contains at least 27 components comprising sesquiterpene hydrocarbons, epoxides, ketones, monoterpene and alipathic alcohols and some unidentified constituents. It is one of the best herbs useful in digestive disorders. It is a keen stimulant for appetite, digestion of $A m a^{12}$.

v) Guggulu- Commiphora Mukul. Being Thikta Kashaya it is Kaphaghna and because of Ushnaveerya (hot potency) it is Vataghna. It aggravates Pitta, it is Deepana (improves fire) and Pachana (digestion) it eliminates aggravated Kapha. Guggulu has a specific action on aggravated Meda. It scrapes (Lekhana) accumulated Meda by its Rooksha (rough)and vishad gunas and by removing obstruction of Meda it facilitates movement of $\operatorname{Vayu}^{22}$. Since it eliminates Kleda (sliminess)from Dhatus, onward movement of nutrients to subsequent Dhatu is facilitated. It contains resin, gum sisamin, cholesterol and a volatile oil. The oil contains steroidal ketone alcohol and aliphatitriol. Steroids contain guggulusterols. It is a potent hypocholesteremic hypolipidemic and Antiatherosclerotic agent.

I. Guduchyadi yoga-

Dose: 2gms. (1gm two times daily)

Route of Administration: Oral

Time of Administration: 6am \& 6pm, empty stomach Duration of therapy: 90 days

Anupan: Takrarishta (butter milk) and Madhu (honey)

\section{Medohar Guggulu-}

Dose - 2gm daily in two divided doses.

Route of Administration - Oral

Time of Administration - 6am \& 6pm empty stomach Duration of therapy -90 days

Anupan (A specific vehicle/medium for taking medicine) - Lukewarm water

\section{Research Methodology:}

i) Study type: Interventional

ii) Masking: Open comparative study

iii) No. Of groups: 2 
iv) Sample size: 25 patients in each group

v) Study site: O.P.D/ I.P.D. wing of P. G. Department of Kayachikitsa, L. K. Ayurveda Hospital, Yavatmal, Maharashtra (D.M.M Ayurveda Mahavidyalaya, Yavatmal).

vi) Duration of Trial: 90 days

\section{Subjective Criteria:}

1.Medaswita, 2. Nirutsaha, 3. Daurbalya, 4. Daurgandhya, 5. Kshudhadhikya, 6. Trishnadhikya,

7. Kshudraswasa, 8. Sarvangajadhya, 9. Atinidra, 10. Sandhivedana

Objective Criteria: weight, B.M.I

Timelines: Total Study Period: Till the enrollment of required no. of patients.

\section{Results}

Table 1: Showing Comparison of Total Effect of Therapy on Two Groups

\begin{tabular}{|l|l|l|l|}
\hline & $\mathrm{t}$ value & $\mathrm{p}$ value & Significance \\
\hline Between group A \& B & -2.857 & $<0.05$ & Yes \\
\hline
\end{tabular}

Table 2. Comparision-Gp. A\& B-Statistical Analysis

\begin{tabular}{|c|c|c|c|c|c|c|c|c|}
\hline \multirow{3}{*}{$\begin{array}{l}\text { Sr. } \\
\text { No. }\end{array}$} & \multirow[b]{3}{*}{ Symptoms } & \multicolumn{4}{|l|}{ No. Of Patients } & \multirow[t]{3}{*}{ Chi-square value } & \multirow[t]{3}{*}{$P$ value } & \multirow[t]{3}{*}{ Significance } \\
\hline & & \multicolumn{2}{|l|}{ Group A } & \multicolumn{2}{|c|}{ Group B } & & & \\
\hline & & Before $\mathrm{T} / \mathrm{t}(\mathrm{BT})$ & After $\mathrm{T} / \mathrm{t}(\mathrm{AT})$ & BT & AT & & & \\
\hline 1. & Medaswita & 25 & 20 & 25 & 12 & 5.54 & $<0.05$ & Yes \\
\hline 2. & Nirutsaha & 18 & 15 & 20 & 09 & 5.98 & $<0.05$ & Yes \\
\hline 3. & Daurbalya & 21 & 16 & 20 & 12 & 1.23 & $>0.05$ & No \\
\hline 4. & Daurgandhya & 20 & 15 & 18 & 08 & 6.65 & $<0.05$ & Yes \\
\hline 5. & Kshudhadhikya & 23 & 19 & 22 & 10 & 6.74 & $<0.05$ & Yes \\
\hline 6. & Trishnadhikya & 18 & 14 & 19 & 08 & 0.68 & $>0.05$ & No \\
\hline 7. & Kshudraswasa & 19 & 14 & 21 & 09 & 3.86 & $<0.05$ & Yes \\
\hline 8. & Sarvangajadhya & 17 & 14 & 19 & 08 & 1.48 & $>0.05$ & No \\
\hline 9. & Atinidra & 22 & 19 & 21 & 09 & 8.94 & $<0.05$ & Yes \\
\hline 10 & Sandhivedana & 20 & 16 & 19 & 07 & 7.49 & $<0.05$ & Yes \\
\hline
\end{tabular}

Total Effect of Therapy: In group A, out of 25 patients, 14 patients $(56.0 \%)$ were effective cured, 04 patients $(16.0 \%)$ had moderate improvement, 02 $(08.0 \%)$ patients had mild improvement, while 05 patients $(20.0 \%)$ showed insignificant result. In group B, out of 25 patients, 09 patients $(36.0 \%)$ got effectively cured, 02 patients $(08.0 \%)$ had moderate improvement, 01 patient $(04.0 \%)$ had mild improvement while 13 patients $(52.0 \%)$ showed insignificant result. It means
Treatment Period: 90 days, Follow up Period: 15 days.

In both groups, patients were advised physical exercise like walking, diet restriction like avoidance of excess oily, spicy foods, excess sweets.

Criteria of Assessment: Subjective Symptoms as well as weight and B.M.I were taken into consideration for the assessment of results. Symptoms Height \& Weight (to calculate BMI) were observed before treatment followed by every 15 days and after completion of trial. Intensity of symptoms were indicated by Grade 0- Normal, Grade 1- Mild, Grade 2- Moderate \& Grade 3- Severe. 
Trishnadhikyaand Sarvangajadhya. It means, Guduchyadi yoga is highly effective remedy as compared to Medohar Guggulu in the treatment of Medoroga.

\section{Statistical Analysis:}

For comparing the effect of treatments on two groups, we use unpaired $t$ test $^{12}$. As the $\mathrm{p}$ value is less than 0.05 , at $5 \%$ level of significance, we reject the hypothesis that the two groups are equally effective. Thus, group A showed more decrease in weight than that in group B.

Quantitative variables were expressed as mean $\pm \mathrm{sd}$ and qualitative variables were expressed in frequency and percentage. Between groups, differences of the quantitative variables were evaluated by t-test and that of the qualitative variables were analysed by chisquared test. Data Was entered in Microsoft excel and the statistical analysis was performed using SPSS. A p-value of $<0.05$ was considered statistically significant.

\section{DISCUSSION}

According to Ayurveda, health is the Samavastha (balanced state) of the Doshas, Dhatus, Malas (faecal matters), Agni and the happy state of Atma, Indriya and manas. Vishamavastha (irregular/ disorder/ unbalanced) of these body elements cause disease. When quantitative, qualitative and functional norms of doshas, dhatus and malas in the body are decrease or increase produce a disease.

Medoroga is defined as the condition in the body in which there is excessive increase in fat and muscle tissue resulting pendulous buttock, abdomen and breast and reduction in the body strength as compared with the body growth. The vitality of such body is much less as compared to its body size. It is undesirable constitution because it comes under one of the eight Ninditapurusha. Medoroga is one of the common problems of MedovahaSrotas. It is Amashaya Samutthavyadhi caused due to disturbance of Agni, excessive diet and behavioural pattern along with high consumption of junk and oily food. Its pathogenesis depends on factors like Agnimandya, Ama and Medovahasrotodushti along with vitiation of kapha and vata leading to the qualitative and quantitative changes of kledakakapha. It is chronic disease that affect many people and contributes to substantial morbidity and mortality. Although there is no magic bullet treatment of obesity but rewarding in terms of reducing complications. Charakacharya said, "Karshyam hi varamsthoulyat". (i.e. Slim persons are better to treat than overweight)

Ayurveda medicine is very effective in this disease because it has the potential to not only suppress the lipid production to optimal level but also offers the advantage of Koshthashuddhi (elimination)so that newly formed lipid would be normal in both quality and quantity. Nowadays, Medoroga is very common problem in our society. It is observed that ayurveda medicine has significant effect on medoroga. It is related to Kayachikitsa discipline. So, Medoroga disease is chosen for present clinical study. In the present study Guduchyadi Yoga and Medohar Guggulu is taken for the clinical trial.

I. Guduchyadi Yoga-This yoga described by Yoga Ratnakar in Medorogachikitsa. It contains Guduchi, Nagarmotha, Triphalachoornam as main ingredients and Takrarishtam, Madhu as anupana. Choornam was prepared as per SOP. Systemic actions of Guduchyadi yoga - Deepana, Pachana, Trishnanigrahana, Mutral, Kaphaghna, jwaraghna, Krimighna, lekhana. It's Doshaghnata- Kaphapittaghna.

II. Medohar Guggulu- This drug contains five ingredients i.e. Shunthi, Chitrak, Marich, Pipal, Nagarmotha. Systemic action of This YogaDeepaniya, Triptighna, Lekhaniya. Its doshaghnata is Kaphapittaghna.

The combination Guduchyadi yoga showed highly significant results on Subjective parameters like Medaswita, Nirutsaha, Daurgandhya, Kshudhadhikya, Trishnadhikya, Kshudraswasa, Atinidra, Sandhivedana, which are due to excess of Meda \& Kapha. The combination acts by its properties like Lekhana, Ushna, Tikshna(Pungent), Medohar, Kaphahar etc.and gives relief in the symptoms. The result is highly significant on objective parameters i.e. Weight \& BMI also. In Medoroga pathogenesis 
Srotorodha by increased Meda \& Kapha causes Tikshnagni \& vataprakopa. In this Guduchyadi yoga by its ushna, tikshna, amapachana gunas reduces srotorodha, which ultimately helps equilibrium in agni and also pacifies Vata. By this way, it is helpful in disintegrating the Samprapti of Medoroga.

\section{CONCLUSION}

Overall effect of the Guduchyadiyoga with proper diet and regimen was more significant and better than the effect of the MedoharGuggulu after treatment and even follow up. In group A patients reported much better mental and physical fitness after the treatment. It can be concluded that the drug is most effective with respect to subjective symptoms like Nirutsaha (83.33\%), Daurbalya (76.19\%), Daurgandhya (75\%), Kshudhadhikya (82.6\%), Kshudrashwasa (73.68\%), Sarvangajadhya (82.35\%), Atinidra (86.36\%), Trishadhikya (77.77\%), Sandhivedana (80\%), in Group A. Result obtained after the study were highly encouraging and free from adverse effects. Inference can be drawn that it is mostly effective on normalising Weight and BMI. A positive direction is advised in order to establish ancient concept of Ayurveda on the basis of modern parameters.

Future Scope: Nowadays, Medoroga is the fifth leading risk of global deaths. Also, the diseases like Diabetes Mellitus, Ischemic heart disease, certain cancers like CA Pancreas, Colon, CA Breast etc. Are attributed to overweight and obesity. So, in this present situation our Ayurveda medicines may prove to be better option to prevent from such complications also from the adverse effects of modern medicines.

\section{REFERENCES}

1. Charak Samhita By Agnivesha, Reprint ed. by Pt. Rajeswaradatta Shastri, Sutrasthana, Ashtouninditeeya: chapter 21, verse3 Varanasi, Chaukhambha Bharati Academy, 2005:P. 407.

2. CharakSamhita By Agnivesha, Reprint ed. by Pt. Rajeswaradatta Shastri, Sutrasthana, Ashtouninditeeya: chapter 21, verse 4, Varanasi, Chaukhambha Bharati Academy, 2005: P.409.

3. Charak Samhita By Agnivesha, Reprint ed. by Pt. Rajeswaradatta Shastri, Sutrasthana, Ashtouninditeeya: chapter 21, verse 20, Varanasi, Chaukhambha Bharati Academy, 2005: P.414.

4. Susrutasamhita Edited by Ayurveda tatvasandipika, Hindi commentary by KavirajAmbikaduttaShastri, Utrasthana Reprint 2017 chapter 15: Doshadhatumalakshayavruddhivijnaneeya: verse19, p 78, Varanasi, Choukhamba Prakashan.

5. Ashtanga Hridayam of Vagbhata, Hindi commentary, Edited by Kaviraja Atrideva Gupta, Reprint-2005, Chapter 11: Doshadivijnaneeya: verse 10, Varanasi: Choukhamba Prakashana, p 86.

6. Madhavanidanam, Madhukoshavyakhya, Reprint Ed, 2016, Hindi commentary by Sri vijayrakshita, Part II, Uttarardha: Chapter 34: Medorogadhikarnidanam, Verse: 5-7, P-35

7. Sharangadhar Samhita By Agnivesha ed. Bramhananda Tripathi, Hindi commentary, Madhyamkhand, dvitiyaadhyaya: verse 111-114, Varanasi, Choukhamba Prakashan: p.99.

8. Bhavaprakasa of Bhavamisra vol.2, English Translation by Prof. K. R. Srikantha Murthy, Madhya khanda: Part III: Sthoulyadhikara: chapter 39: verse 1, 2, p. 502, Ed. 3 ${ }^{\text {rd }}, 2005$, Varanasi, Choukhamba Krishnadas academy.

9. Yoga Ratnakared. By Dr MadhamShetty Suresh Babu, E Medoroganidanam, verse 2, edition 2018, Uttarakhanda vol. II, P.806, Varanasi, choukhambaprakashan

10. Yoga Ratnakared. By Dr MadhamShetty Suresh Babu, E Medoroga, verse 2, edition 2018, Uttarakhanda vol. II, P. Medoroga Chikitsa (10/17) p.809

11. Bhaishajya Ratnavali (Medorogachikitsa) (39/43) of Shri. GovindaDasji (3Vols.) edited 2006 By Ed. Brahmashankar Mishra and Eng. TriKanjiv Lochan 2006 Chaukhambha Sanskrit bhavan series 67.

12. Ashtanga Sangraha, Induvirachita shashilekha vyakhya, tika, Choukhamba Prakashana, Varanasi, Chapter 12: Vividhaoushadhavijnaniya: verse-38, P. 122

13. Ashtanga Sangraha, Induvirachita Shashilekha vyakhya, tika, Choukhamba Prakashana, Varanasi, Chapter 12: Vividhaoushadhavijnaniya: verse-22, P. 120

14. Ashtanga Sangraha, Induvirachita shashilekha vyakhya, tika, Choukhamba Prakashana, Varanasi, Chapter 12: Vividhaoushadhavijnaniya: verse-23, P. 120

15. Ashtanga Sangraha, Induvirachita Shashilekha vyakhya, tika, Choukhamba Prakashana, Varanasi, 
Chapter 12: Vividhaoushadhavijnaniya: verse-24, P. 120

16. Charak Samhita, English translation by P. V. Sharma, Choukhamba, Chikitsa Sthana, Chapter: 15: Grahanidosha Chikitsitam: Verse 117, 118,119,120,121: p. 259.

17. Charak Samhita, English translation by P. V. Sharma, Choukhamba, Sutrasthana, chp:17: Annapanavidhiadhyaya: verse 245, 246: p. 215.

18. Ashtanga Sangraha, Induvirachita shashilekha vyakhya, tika, Choukhamba Prakashana, Varanasi, Chapter 12: Vividhaoushadhavijnaniya: verse-30, P. 121

19. Ashtanga Sangraha, Induvirachita shashilekha vyakhya, tika, Choukhamba Prakashana, Varanasi, Chapter 12: Vividhaoushadhavijnaniya: verse-32, P. 121

20. Ashtanga Sangraha, Induvirachita shashilekha vyakhya, tika, Choukhamba Prakashana, Varanasi, Chapter 12: Vividhaoushadhavijnaniya: verse-27, P. 120
21. Ashtanga Sangraha, Induvirachita shashilekha vyakhya, tika, Choukhamba Prakashana, Varanasi, Chapter 12: Vividhaoushadhavijnaniya: verse-28, P. 120

22. Ashtanga Sangraha, Induvirachita Shashilekha vyakhya, tika, Choukhamba Prakashana, Varanasi, Chapter 12: Vividhaoushadhavijnaniya: verse-38, P. 122

23. Mahajan B. K. Methods of Biostatistics, Jaypee Publishers, New Delhi, Page No. 129.

\section{Source of Support: Nil \\ Conflict of Interest: None Declared}

How to cite this URL: Anita Renni:A Comparative Study Of Guduchyadi Yoga And Medohar Guggulu In The Management Of Medoroga. International Ayurvedic Medical Journal \{online\} 2020 \{cited November, 2020\} Available from:

http://www.iamj.in/posts/images/upload/2587_2594.pdf 